\title{
Capital, Social Reproduction, and the Rise of Inequality
}

\author{
Alexis Spire
}

For a reader unfamiliar with the rudiments of economics, Thomas Piketty's book has the great merit of presenting an accessible history of the transformations of capital and wealth distribution, supported by numerical data and situated in the footsteps of the classic thinkers in the field (Thomas Malthus, David Ricardo, Karl Marx, and Simon Kuznets). The historical and political perspective it offers on inequality today - through comparisons with past situations, particularly inequalities measured over two centuries in Europe and the United States-makes it an indispensable work for anyone seeking to reflect on the evolution of capitalism or on the current crisis and how to bring it to an end. Piketty explores the relations between large aggregates such as demographic growth, national income, return on capital, inflation, and debt, explaining in an ever-instructive manner how they interact and what effect they have on the dynamic of inequality. The imposing statistical apparatus (both in the book and on the author's website) demonstrates the value of a project involving approximately thirty researchers worldwide and gives access to unprecedented data on wealth distribution over the last two centuries.

These qualities render the book's worldwide success fully merited. Here, however, I would like to take the invitation expressed in its introduction seriously and read it not as an economic treatise but as a contribution to the social sciences as a whole. In this regard, it can be hoped that the praise heaped upon the work 
by numerous Nobel Prize winners will prompt economists to renew dialogue with the other social sciences, from which they have turned in favor of mathematical models that are increasingly disconnected from historical or social realities. The trail blazed by Piketty is radically innovative not only in the knowledge it produces and the policies it proposes, but also in terms of its academic positioning, notably when he advocates for economics "as a subdiscipline of the social sciences, alongside history, sociology, anthropology, and political science." ${ }^{1}$ Without waiting for this potential reconciliation, in what follows I will suggest how certain results of this now indispensable work can open up fruitful perspectives in sociology and political science.

\section{How to Understand Inequality and Perceptions of It?}

In order to give substance to his interpretation of inequality, Piketty uses the notion of social class, which he defines according to levels of income and volume of wealth. He divides society into four primary groups: the "lower class" comprising the 50 percent of the population at the lower end of the salary and wealth hierarchy, the "middle class" representing the middle 40 percent, the "upper class" consisting of the top 10 percent, and finally the "dominant class," limited to the wealthiest 1 percent. To refine this portrait, he paints a highly convincing picture of the upper decile by emphasizing its contrasting character: as one rises through this stratum of the most wealthy, the share of income from labor tends to decrease, while the share of income from capital becomes larger and larger. ${ }^{2}$ For the intermediary level of the social hierarchy, Piketty coins the idea of the "patrimonial (or propertied) middle class," linked to widening access to property ownership-a potentially useful notion for further work on the evolving relations between small property owners and private capitalism. The possession of patrimonial assets should play a central role in our understanding of social differences, as it is likely to have a lasting influence on the worldview of certain categories of the population as well as on their relation to politics and the state.

The huge advantage of this standardized definition of classes based on economic capital is that it enables comparisons of the distribution of wealth in countries separated by large geographical or even temporal distances. This is the "beauty" of the deciles; they "are defined in exactly the same way in different societies," 3 provided one accepts the rather audacious hypothesis that the fiscal systems of all the countries studied record disparities in income and wealth with equal reliability. We can thus measure the difference between Scandinavian countries during the 1970s, where the richest 10 percent commanded a quarter of national income, and

1. Thomas Piketty, Capital in the Twenty-First Century, trans. Arthur Goldhammer (Cambridge/London: Harvard University Press, 2014), 573. 
the United States of today, where this same portion is monopolized by the richest 1 percent. Yet though this comparison is undeniably compelling, this indicator relegates another fundamental aspect of inequality to the background: cultural capital, which refers to all of the resources (institutionalized or embodied) that can lend legitimacy to domination. ${ }^{4}$ In an initial estimate this can be measured by education level, but it can also refer to other non-economic resources such as language skills or access to international mobility. ${ }^{5}$ In Capital in the Twenty-First Century, Piketty takes education level into consideration as a determining factor of income, but he never treats it as an independent variable in social differentiation. The structuring role of cultural capital in social reproduction is certainly less crucial now than it was at the time of Pierre Bourdieu and Jean-Claude Passeron's Inheritors, ${ }^{6}$ due to the widening of mass education and the growing weight of economic inheritance. However, the increasing magnitude of accumulated wealth should not lead us to forget the importance of cultural and symbolic capital, which can also increase inequality from one generation to the next. Piketty's analysis according to levels of income and wealth nevertheless makes it possible to sum up the hegemony of the dominant class: at Harvard, the parents of graduating students belong on average to the richest 2 percent of the American population, while the parents of students at Sciences Po belong to the richest 10 percent in France. In reality, the selection process takes place much earlier and produces dynamics of relegation that are not limited to the most prestigious institutions: as forms of residential and school segregation become more pronounced, they transform strategies of social reproduction, which come to depend more heavily on the economic resources needed to live in neighborhoods that give access to the best schools. ${ }^{7}$ Economic capital is thus increasingly used as a means of securing resources of cultural capital, which can subsequently, by way of the "right" degree, be transformed into cold hard cash.

Another major contribution of Piketty's work is its clear-sighted interpretation of the explosion of economic inequality, distinguishing between the forms connected to labor income and those linked to capital income. His demonstration of the soaring compensation for "supermanagers" in the United States, and more specifically for the top thousandth ( 0.1 percent of the highest salaries), is very

4. Pierre Bourdieu, "The Forms of Capital," trans. Richard Nice, in Handbook of Theory and Research for the Sociology of Education, ed. John G. Richardson (New York: Greenwood Press, 1986), 241-58.

5. Anne-Catherine Wagner, Les classes sociales dans la mondialisation (Paris: La Découverte, 2007).

6. Pierre Bourdieu and Jean-Claude Passeron, The Inheritors: French Students and Their Relation to Culture [1964], trans. Richard Nice (Chicago: University of Chicago Press, 1979).

7. Tim Butler and Agnès Van Zanten, "School Choice: A European Perspective," Journal of Education Policy 22, no. 1 (2007): 1-5; Jean-Christophe François and Franck Poupeau, "Les déterminants socio-spatiaux du placement scolaire. Essai de modélisation statistique appliquée aux collèges parisiens," Revue française de sociologie 49, no. 1 (2008): 93-126. 
convincing. ${ }^{8}$ However, the avenues used to account for the resulting disparity with the "Old World" raise a question that the numerical data does not explain: Why does the colossal increase of very high salaries in the United States appear legitimate in the eyes of the broader public, while much smaller levels of wealth prompt indignation in Europe? Piketty favors an interpretation in terms of social norms that he associates with "beliefs": the educated elite on each side of the Atlantic apparently have distinct ways of showcasing their merits and personal qualities. This difference represents a genuine area of investigation for future comparative research. The evolution of these systems of representation cannot be understood solely on the basis of what elites say about them, for they are also created by institutions that structure political discourse and action. ${ }^{10}$ More generally, it would be useful to produce a genealogy of relations to the state and inequality on both sides of the Atlantic by providing an account of the different capacities of the dominant classes to legitimize their hegemony and to wield power over state action. In the United States, the influence that the richest 1 percent wields over the behavior of politicians flows from the importance of the business sector in politics, ${ }^{11}$ especially through its stranglehold over the financing of electoral campaigns. ${ }^{12}$ This last observation raises the more political question of the conditions that would make a reduction in inequality possible.

\section{How to Combat Inequality?}

Demonstrating in magisterial fashion that the rise in inequality is consubstantial with the recent evolution of capitalism, Piketty refuses to inscribe this evolution within the natural order of things. The entire final section of his book is a plea for more concerted regulation of the accumulation of wealth, via a return to a truly progressive tax on the highest incomes (with a top marginal rate of 80 percent on incomes above 500,000 dollars) and the implementation of a progressive tax on capital. Such a tax reform would, he argues, reinforce social justice without threatening the productivity or the growth of the countries applying it. Nevertheless, this "useful utopia," which envisages the intervention of state power as a corrective measure, should not obscure the fact that there are other ways of achieving a better distribution of position and wealth that can be implemented preventively. The

8. Piketty, Capital, 314.

9. Ibid., 332 and 512.

10. Sven Steinmo, Kathleen Ann Thelen, and Franck Longstreth, eds., Structuring Politics: Historical Institutionalism in Comparative Analysis (Cambridge: Cambridge University Press, 1992).

11. Jacob S. Hacker and Paul Pierson, Winner-Take-All Politics: How Washington Made the Rich Richer - And Turned its Back on the Middle Class (New York: Simon and Schuster, 2010). 
state could use legislation to strengthen the negotiating power of employees, guarantee more protection in the labor market, or increase the minimum wage. It might also choose to limit the drive for profitability, especially in sectors of public interest such as education, health, housing, and energy, or to promote forms of capital management that involve more cooperative decision-making methods.

If Piketty favors taxation over any other method of regulation, this is surely because he is more attentive to the inequality produced by the economic rent of the most privileged than that which results from relations of domination playing out on other levels of the social hierarchy. In fact, he focuses on two types of inequality: the inequality that arises from the opposition between labor income and capital income, and the inequality among the working population linked to the sharp rise in compensation for "supermanagers." Throughout his argument, Piketty measures a country's meritocracy in light of labor income's share of the total wealth, and shows that since the 1970s this share has tended to decline in most advanced countries. On a macroeconomic level, return on capital is thus always greater than the rate of growth $(r>g)$, which prompts him to point out the risk that "the past tends to devour the future: wealth originating in the past automatically grows more rapidly, even without labor, than wealth stemming from work, which can be saved." 13 As a result, the progressive tax on capital appears to be the most suitable instrument for ensuring that the portion of income stemming from rent and inheritance is reduced to the smaller share, leaving only the inequalities arising exclusively from labor income. What is important is to preserve a meritocracy founded on individual ability, which Piketty places at the center of our "democratic modernity." 14 There are therefore two systems of inequality: an acceptable one linked to labor income (provided the staggering compensation of the "supermanagers" in the United States is prevented through taxation), and an illegitimate one tied to rent and inheritance. The presuppositions that underpin such a worldview are not made completely explicit, however. Notably, this position accepts as an established fact that abilities are acquired through education, work, and professional success, independently of inherited social and cultural capital.

If Piketty's analysis of the measures necessary to contain the very highest remunerations is convincing, he has less to say about the possibility of restraining the increasing inequality between the top five deciles and the rest of society. The economic impoverishment and narrowing mobility prospects of those deprived of any form of capital do not simply reflect a problem of the accumulation or redistribution of wealth; this inequality arises from an intensification of the forms of domination among wage-earners and an increase in social segregation. The advent of a genuine meritocracy of individuals would not change much, as this situation stems more from the marginalization of the social groups that possess the least. Historically, it was political and union mobilization that made it possible to attenuate the inequality inherent to the functioning of the market. In this respect, the assessment 
presented in Capital in the Twenty-First Century calls once again for new research in political sociology that seeks to understand the reasons behind the erosion of forms of collective resistance.

Toward the end of the book, the bold idea of implementing a European or even a global tax on capital raises the question of the conditions that would make social and political change possible in modern societies. In the preceding sections, Piketty rightly insists on the central role of the two world wars in the redistribution of the cards on both sides of the Atlantic. However, the role of political parties, unions, and more broadly of social mobilization are scarcely mentioned in his discussion. Admittedly, the work opens with a conflict opposing South African miners and their managers over wage increases, and it mentions Occupy Wall Street and its slogan "we are the 99 percent" (largely inspired by the work of Piketty and Emmanuel Saez) on several occasions. But apart from these two occurrences, the dynamic of social movements and their capacity to impose changes in institutions and forms of regulation are relatively absent. The discussion seems to assume that the development of the right instrument of economic regulation-as long as it serves the general interest and is familiar to the widest possible public-is the primary condition for a reduction in inequalities in peacetime.

To convince his readers, Piketty explores the technical details of the measures he proposes and considers the practical implications they could entail. Yet he remains relatively silent on how such a radical reform might be achieved. Unless there is an upheaval like the one experienced by European countries after the First World War, it is difficult to see what parliamentary majority could adopt his project of a progressive tax on capital to prevent the wealthiest from accumulating and passing on even greater wealth. When he informs us that the average member of the US House of Representatives is worth fifteen million dollars, ${ }^{15}$ it is hard not to conclude that such a measure would only see the light of day if it were carried by a mobilization capable not only of changing the tax system but also of overturning the entire established social order. When one thinks of the resistance generated in France by a wealth tax with a maximum rate of 1.8 percent (today reduced to 1.5 percent), one can imagine the hostility that would be provoked by the tax envisioned by Piketty, deducting up to 10 percent per year from fortunes of over a billion euros. ${ }^{16}$ At such a level of taxation, the fact that a plan is clearly to the advantage of the vast majority is not enough for it to be implemented by the people's representatives, even if elected. In the case of France, the proposition to merge income tax and social security contributions (the contribution sociale généralisée) presented in Landais, Piketty, and Saez's call for a fiscal revolution is illuminating. ${ }^{17}$

15. Ibid., 646, n. 42.

16. Even if we account for the amounts collected by the property tax, such a tax on capital would constitute a major upheaval, especially in countries that have entirely given up on taxing large fortunes.

17. Camille Landais, Thomas Piketty, and Emmanuel Saez, Pour une révolution fiscale. Un impôt sur le revenu pour le XXI ${ }^{e}$ siècle (Paris: Le Seuil, 2011). 
Initially defended by the Socialist Party and then abandoned when they came to power, the fate of this proposal shows that even the most appealing of reforms can never materialize if they are not supported by grassroots organizations and activist networks, in short by political forces likely to mobilize in order to push them through. To successfully implement a tax that would significantly and annually reduce the largest fortunes would require a social movement of such a scale that it could simultaneously attack inequalities in access to education, health care, housing, and employment-in other words, a movement that could question all existing institutions. There is clearly a disjunction here between the radicalism of the vision of a fiscal democracy presented in Capital in the Twenty-First Century and the author's desire to consistently inscribe its implementation within the framework of a system of political representation that has already broadly contributed to increasing the inequality he denounces.

More generally, this last point leads on to another question that comes to mind after finishing Capital in the Twenty-First Century: Why does the recent explosion of inequality in income and wealth not give rise to more resistance among the vast majority of those who do not benefit from it? Of course, one might consider that the now global success of Piketty's book will serve as the first step in a process of growing awareness about the scale of current inequality, a process that could call the system of wealth distribution into question. However, many obstacles still remain that prevent the most dominated groups from clearly understanding the best means of defending their interests. Instead, for the time being it is the champions of neoliberalism, led by the Financial Times, ${ }^{18}$ who have called for mobilization. The violence of their attacks is undoubtedly commensurate with the importance of Piketty's book, both scientifically and politically. For social scientists, the scope of the data recorded in the work encourages a return to the question posed by American political scientists after George W. Bush won popular support for lowering taxes for the most wealthy ${ }^{19}$ : Why, in the different countries studied by Piketty, do populations consent so willingly to their domination and to the increase in inequality? This would present a real agenda for research aiming to study the evolving representation of inequality, social justice, and the role of state power as a regulating authority. Beyond a simple sociology of social imaginaries, it would mean underlining the influence exerted by entrepreneurs of norms (journalists, think tanks, and political actors) in the promotion of a society where modernity is necessarily combined with the scaling back of the state. The possibility cannot be

18. See the accusatory article by the editorial writer Chris Giles in the May 23, 2014 edition, and the convincing response Piketty published on his site a few days later: http:// piketty.pse.ens.fr/files/capital21c/en/Piketty2014TechnicalAppendixResponsetoFT.pdf. 19. Larry Bartels, Unequal Democracy: The Political Economy of the New Gilded Age (Princeton: Princeton University Press, 2008); Isaac Martin, Rich People's Movements: Grassroots Campaigns to Untax the One Percent (Oxford: Oxford University Press, 2013). 
ruled out that the illusions bolstered by the celebration of a meritocracy of individuals have also contributed to discrediting any form of collective resistance and to legitimizing the sharp rise in salary gaps. How long will this last? After reading Capital in the Twenty-First Century, one is reminded of Antonio Gramsci's phrase, written at the beginning of the last century but still pertinent for the decades ahead. One can be "a pessimist because of intelligence, but an optimist because of will." 20

$$
\begin{array}{r}
\text { Alexis Spire } \\
\text { Iris-CNRS/EHESS }
\end{array}
$$

20. Antonio Gramsci, "Letter to Carlo, December 19, 1929," in Letters From Prison, ed. 1994), 299. 